\title{
Endodontik sebeplerle çekilmiş dişlerin mineral içeriğinin SEM-EDX yöntemi ile incelenmesi
}

\author{
Keziban Olcay ${ }^{1}$, Hanife Ataoğlu², Sema Belli ${ }^{3}$
}

Selcuk Dent J, 2016; 3: 107-119

Başvuru Tarihi: 01 Aralık 2016 Yayına Kabul Tarihi: 05 Ocak 2017

\section{Öz \\ Endodontik sebeplerle çekilmiş dişlerin mineral içeriğinin SEM-EDX yöntemi ile incelenmesi}

Amaç: Bu araştırmanın amacı; endodontik tedavi sonrasında diş dokularının mineral içeriğinde meydana gelen değişikliklerin, dişin farklı bölgelerinde Taramalı Elektron Mikroskobu-Enerji Dağılımlı X Işını Analizi (SEM-EDX) yöntemi kullanılarak incelenmesidir.

Gereç ve Yöntemler: Bu çalışmada başarısız olmuş kanal tedavili dişler arasından çekim endikasyonu konulan, 20 ade tek köklü insan daimi diși ve 20 adet kök kanal tedavisi görmemiş, ortodontik veya periodontal nedenlerle çekilmiş, çürüksüz, restorasyonsuz, sağlam tek köklü insan daimi dişi olmak üzere toplam 40 adet diş kullanılmıştır. Dişler kanal tedavisi sonrasında yapılarındaki mineral miktarında olası değişikliklerin endodontik tedavide başarısızlık ile ilişkisinin araștırılması amacıyla SEM-EDX analizine gönderilmek üzere $\% 10$ 'luk formalin solüsyonunda bekletildi. SEM-EDX analizi sırasında, her dişin bir yarısı, apikal, orta ve koronal olmak üzere standardize edilmiş 3 ayrı noktadan, elementel içerik ve elementel dağılım açısından 300 büyütme altında analiz edildi. Dişin diğer yarısı ölçüm amacıyla kullanılmadı. Bu analiz sırasında, oksijen, karbon, kalsiyum, fosfor, magnezyum, sodyum, sülfür, çinko, alüminyum, klor ve $\mathrm{Ca} / \mathrm{P}$ ile ilgili veriler değerlendirildi. SEM-EDX ile elde edilen verilerin istatistiksel analizi ise tek yönlü varyans analizi ile yapıldı.

Bulgular: SEM-EDX analizinin sonuçlarına göre kök kana tedavisi olan dişler ve kontrol grubu arasında karbon, kalsiyum, fosfor, alüminyum ve klor ile ilgili anlamlı fark bulunmuştur $(p<0,01)$. İi grup arasında oksijen, magnezyum, sodyum, sülfür, çinko ve $\mathrm{Ca} / \mathrm{P}$ miktarı ile ilgili anlamlı bir fark bulunamamıştır $(p>0,05)$. Apikal, orta ve koronal bölgeler açısından hiçbir grupta anlamlı bir farklılık yoktur $(p>0,05)$.

Sonuç: Bu çalışmada, kök kanal tedavisi sonrasında, dişin farklı bölgelerinde bir fark gözlenmezken, diş dokusunda karbon, kalsiyum, fosfor, alüminyum ve klor mineralleri açısından anlamlı farklılıklar olduğu sonucuna varılmıştır.

\section{ANAHTAR KELIMELER}

Çekim, elektron tarama, endodonti; kanal tedavisi yenileme; mineral içerik

\section{ABSTRACT \\ Analysis of mineral content of the teeth extracted for endodontic reasons using with SEM-EDX method}

Background: The purpose of this study is to investigate the changes in the mineral contents of dental tissues in various areas of the tooth using Scanning Electron Microscopy/Energy Dispersive X-Ray Analysis (SEM-EDX) method after endodontic therapy

Methods: In this study totally 40 teeth; as twenty single-rooted human permanent teeth which were decided to be extract due to failed endodontically treated teeth and twenty single-rooted extracted human intact teeth which had no root canal therapy, no caries or restoration, extracted for periodontal or orthodontic reasons were used. The teeth were kept in $10 \%$ formalin solution until send for SEM-EDX analysis to investigate the probable relationship between mineral content of the teeth after root canal therapy and failure in endodontic therapy. While SEM-EDX analysis, half of every tooth was analyzed based on elemental content and elemental distribution from standardized three different points as apical, middle and coronal, under $300 \mathrm{X}$ magnification. For the purpose of measurement, the other half of the tooth was not used. During this analysis, the data related oxygen, carbon, calcium, phosphorus, magnesium, sodium, sulphur, zinc, aluminum, chlorine and $\mathrm{Ca} / \mathrm{P}$ were evaluated. Statistical analysis of the data obtained from SEM-EDX was done by using One Way Anova test.

Results: According to the SEM-EDX analysis there was a significant difference regarding carbon, calcium, phosphorus, aluminum and chlorine between the root canal therapy group and the control group $(p<0.01)$. A significant difference was not found regarding the quantity of oxygen, magnesium sodium, sulphur, zinc and $\mathrm{Ca} / \mathrm{P}$ between two groups $(p>0,05)$. There is no significant difference about apical, middle and coronal areas in any group $(p>0,05)$.

Conclusion: In this study it is concluded that, even though there were no changes observed at various areas of the tooth after root canal therapy, there are significant differences regarding carbon, calcium, phosphorus, aluminum and chlorine minerals in dental tissue.

\section{KEYWORDS}

Extraction, electron scanning, endodontics, retreatment, mineral content

\footnotetext{
1 İstanbul Medipol Üniversitesi Diş Hekimliği Fakültesi Endodonti Anabilim Dalı, İstanbul

2 Selçuk Üniversitesi Diş Hekimliği Fakültesi Ağız, Diş ve Çene Cerrahisi Anabilim Dalı, Konya

${ }^{3}$ Selçuk Üniversitesi Diş Hekimliği Fakültesi Endodonti Anabilim Dalı, Konya
} 
Mine ve dentinin yapısı, organik ve inorganik içeriği temel alınarak tanımlanmakla beraber, yüksek oranda hidroksiapatit kristallerinden $\left(\mathrm{Ca}_{3}\left(\mathrm{PO}_{4}\right)_{5} \mathrm{OH}\right)$ oluşmaktadır (Arı ve Erdemir 2005). Hidroksiapatit kristalinde bulunan kalsiyum $(\mathrm{Ca})$ ve fosfor $(\mathrm{P})$ dental sert dokuların ana inorganik komponentidir (Sayın ve ark. 2007, Cobankara ve ark 2011) ve ağılık olarak sırasıyla \%34-39 ve \%16-18 arasında değişiklik göstermektedir (Kang ve ark. 2004). Minede ise; hidroksiapatit matrikste yer alan katyonik (Ca) ve anyonik $(\mathrm{OH})$ merkezlerde değişen sayılarda katyon ve anyonlar içeren düzenli büyüme tabakaları bulunmaktadır. Ana katyonlar: sodyum ( $\mathrm{Na})$, potasyum $(\mathrm{K})$, magnezyum $(\mathrm{Mg})$; ana anyonlar ise flor $(\mathrm{F})$ ve klor (Cl)'dur (Kang ve ark. 2004).

Bunların yanında, cıva $(\mathrm{Hg})$, baryum $(\mathrm{Ba})$, kurşun $(\mathrm{Pb})$, gümüş $(\mathrm{Ag})$, çinko $(\mathrm{Zn})$, bakır $(\mathrm{Cu})$, nikel $(\mathrm{Ni})$, titanyum (Ti), sülfür (S) gibi bazı elementlerin miktarının, kök kanal tedavisi sırasında uygulanan farklı kimyasal maddeler, şelasyon ajanları, gutta perka çözücüleri, kanal dolgu patları ve/veya beyazlatma ajanları sonucunda değişikliğe uğradığı gözlenmiştir (Rotstein ve ark. 1996, Doğan ve ark. 2001, Doğan ve Çalt 2001, Sayın ve ark. 2009, Borges ve ark. 2012). Bu Ca/P oranında meydana gelen değişiklik, dentin permeabilitesi ile organik/inorganik yapının oranında önemli bir farklıı̆ga neden olarak, dental materyallerin diş dokusuna bağlantısını ve sızdırmazlık özelliklerini olumsuz yönde etkilemektedir (Timpawat ve ark. 2001, Saleh ve ark. 2002, De-Deus ve ark. 2006, Mello ve ark. 2009).

Irrigasyon esnasında kanal dentininin ve koronal dentinin irrigasyon solüsyonlarıyla temas halinde olması, kanal dolgu materyalinin ve/veya üst restorasyon materyalinin diş dokularına bağlanmasını etkilemektedir (Celik ve Belli 2012). Aynı şekilde kanal tedavisi sırasında kullanılan kanal dolgu patları da kök dentini ile temas etmekte ve diş dokusunun mineral içeriğinde değişikliklere sebep olabilmektedir (Schafer ve Zandbiglari 2003, Resende ve ark. 2009, Flores ve ark. 2010).

Kök dentinindeki mineral içeriğini araştırmak için kullanılan yöntemler arasında SEM-EDX'in diğer yöntemlere(Mass spectrometry (MS), Neutron activation analysis (NAA), inductively coupled plasma atomic emission spectroscopy (ICP-AES), inductively coupled plasma spectrometry (ICPS), laser ablation inductively coupled plasma mass spectrometry (LA-ICPMS), inductively coupled plasma mass spectrometry (ICP$\mathrm{MS})$, high-resolution inductively coupled plasma mass spectrometry (HR ICP-MS) vb.) göre üstünlüğü, örnek üzerinde $200 \mu \mathrm{m}$ derinliğe kadar istenilen alanın morfolojisini, elementel kompozisyonu gösterebilmesi ve ilgili alanda haritalama yapılmasına izin vermesidir (Gandolfi ve ark. 2010).
Bu araştırmanın amacı; kök kanal tedavisi sonrası diş dokularının mineral içeriğinde meydana gelen değişikliklerin, dişin farklı bölgelerinde SEM-EDX yöntemi kullanılarak incelenmesi ve mineral miktarındaki değişikliklerin endodontik tedavide başarısızlık ile olası ilişkisinin araştııımasıdır.

\section{GEREÇ VE YÖNTEM}

$\mathrm{Bu}$ çalışma Selçuk Üniversitesi Diş Hekimliği Fakültesi Etik Kurulu tarafından 2011/02-08 nolu karar ile onaylanmış olup, Helsinki Deklarasyonu Prensipleri 'ne uygun şekilde, Ocak 2011- Mayıs 2012 tarihleri arasında yapılmışıı. Çalışmaya katılmış olan her hasta, bilgilendirilmiş olur formunu okumuş ve imzalamıştır.

SEM-EDX analizi, Selçuk Üniversitesi İleri Teknoloji Araştırma ve Uygulama Merkezi Laboratuarı'nda ZEISS EVO LS10 LaB6 (Carl Zeiss Microscopy GmbH, 07745 Jena, Germany) model Taramalı Elektron Mikroskobu (SEM) ile yapılmıştır. Örneklerin hazırlanmasında kullanılan kimyasalların marka ve yüzdeleri Tablo 1'de verilmiştir.

Çalışmada, Selçuk Üniversitesi Diş Hekimliği Fakültesi Endodonti Anabilim Dalı'na yönlendirildikten sonra, çekim endikasyonu konulan önceden kanal tedavisi görmüş dişler, çekimden sonra SEM-EDX analizine kadar bakteri kontaminasyonunu engellemek amaciyla \%10'luk formalin solüsyonunda bekletildi. Analiz için çekilen dişler arasından tek köklü 20 adet diş rastgele seçildi. Kontrol grubu olarak, ortodontik veya periodontal nedenlerle çekilmiş, çürüksüz, restorasyonsuz ve kök kanal tedavisi görmemiş tek köklü daimi dişlerden 20 adet diş rastgele seçildi. Benzer şekilde kontrol grubu dişleri de SEM-EDX analizine kadar \%10'luk formalin solüsyonunda bekletildi.

Analizden iki gün önce, tüm dişlerin dış yüzeylerinde bulunan doku artıkları seyreltilmiş nitrik asit ile yıkanmış diş fırçası ve distile su yardımıyla temizlendi. Daha sonra sırasıyla n-hegzan, 2propanol ve aseton kullanılarak, her bir solüsyonda ve sırasıyla olmak üzere 10'ar dakika boyunca ultrasonik banyoya tabi tutuldu (Kang ve ark. 2004). $\mathrm{Bu}$ işlemin hemen ardından dişler distile su ile yıkandı. Doku artıklarından arındırıldıktan sonra, tek köklü dişlerin bukkal ve lingual yüzeylerinde su soğutması altında olmak üzere bir elmas separe yardımıyla dikey yönde oluklar açıldı. Bu referans oluklar yardımıyla her bir dişin dikey olarak ortadan ikiye ayrılması sağlandı. Her diş için bir parça analiz için kullanıldı, diğer parça çalışmaya dahil edilmedi. Daha sonra kanal dolgu maddeleri ince bir spatula 
yardımıyla mekanik olarak uzaklaştırıldı. Elde edilen örnekler SEM-EDX analizinden önce kuruması için 12 saat süresince $100^{\circ} \mathrm{C}$ 'de etüvde bekletildi.

Her dişin bir yarısı, apikal (apeksten $1 \mathrm{~mm}$ koronalde), orta (apeksten $3 \mathrm{~mm}$ koronalde) ve koronal (apeksten 5 $\mathrm{mm}$ koronalde) olmak üzere standardize edilmiş 3 ayrı noktadan, elementel içerik ve elementel dağılım açısından 300 büyütme altında analiz edildi.

SEM-EDX analizi sonucunda elde edilen oksijen, karbon, kalsiyum, fosfor, magnezyum, sodyum, sülfür, çinko, alüminyum, klor ve $\mathrm{Ca} / \mathrm{P}$ ile ilgili verilerin istatistiksel analizi Tek Yönlü Varyans Analizi kullanılarak SPSS 17.0 (SPSS Inc, Chicago, IL) programında yapıldı.

\section{Bulgular}

Kontrol grubundan rasgele seçilen bir örnekte yapılan analiz sonucunda elde edilen bulguları gösteren grafikler ve görüntüler sırasıyla Grafik 1, Grafik 2, Grafik 3 ve Resim 1, Resim 2 ve Resim 3'de gösterilmiştir.

Kanal tedavili dişler grubundan rasgele seçilen bir örnekte yapılan analiz sonucunda elde edilen bulguları gösteren grafikler ve görüntüler sırasıyla Grafik 4, Grafik 5, Grafik 6 ve Resim 4, Resim 5 ve Resim 6'da gösterilmiştir.

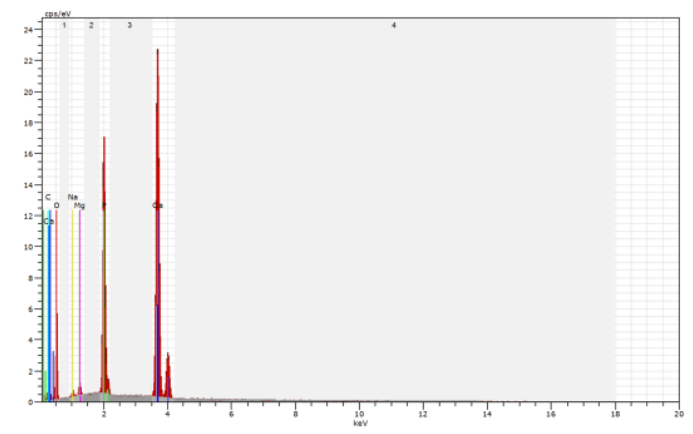

Grafik 1.

Kontrol grubunda seçilen dişte apikal bölgede SEM-EDX analizi sonucunda elde edilen bulguları gösteren grafik

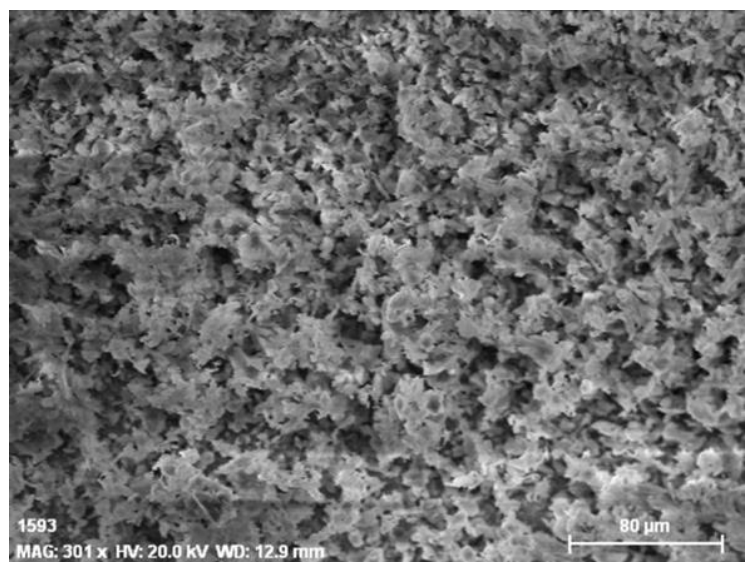

Resim 1.

Grafik 1.'de gösterilen alanın elektron mikroskopta elde edilen görüntüsü $(\times 300)$
Tablo 1. Örneklerin hazırlanmasında kullanılan kimyasallar

\begin{tabular}{|c|c|c|}
\hline Kimyasallar & İçerik & Üretici Firma \\
\hline Formalin & $\% 10$ formaldehit & $\begin{array}{l}\text { Merck KGaA, } \\
\text { Darmstadt, } \\
\text { Almanya }\end{array}$ \\
\hline N-hegzan & \%95 n-hegzan & $\begin{array}{c}\text { Referans Kimya } \\
\text { Ltd, Ankara, } \\
\text { Türkiye }\end{array}$ \\
\hline Propanol & \%99,5 propanol & $\begin{array}{c}\text { Referans Kimya } \\
\text { Ltd, Ankara, } \\
\text { Türkiye }\end{array}$ \\
\hline Aseton & \%99 aseton & $\begin{array}{c}\text { Referans Kimya } \\
\text { Ltd, Ankara, } \\
\text { Türkiye }\end{array}$ \\
\hline
\end{tabular}

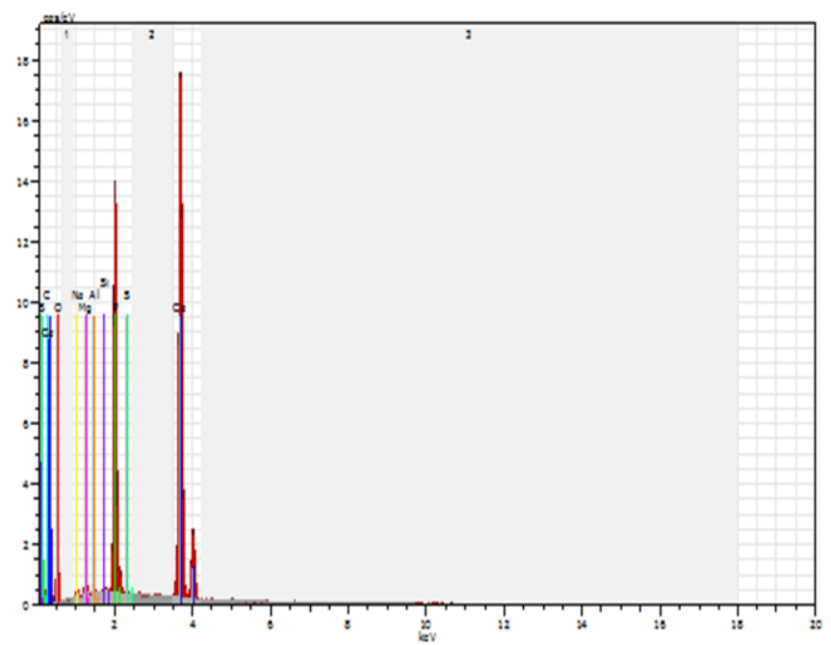

Grafik 2.

Kontrol grubunda orta üçlüde SEM-EDX analizi sonucunda elde edilen bulguları gösteren grafik



Resim 2.

Grafik 2.'de gösterilen alanın elektron mikroskopta elde edilen görüntüsü $(\times 300)$ 


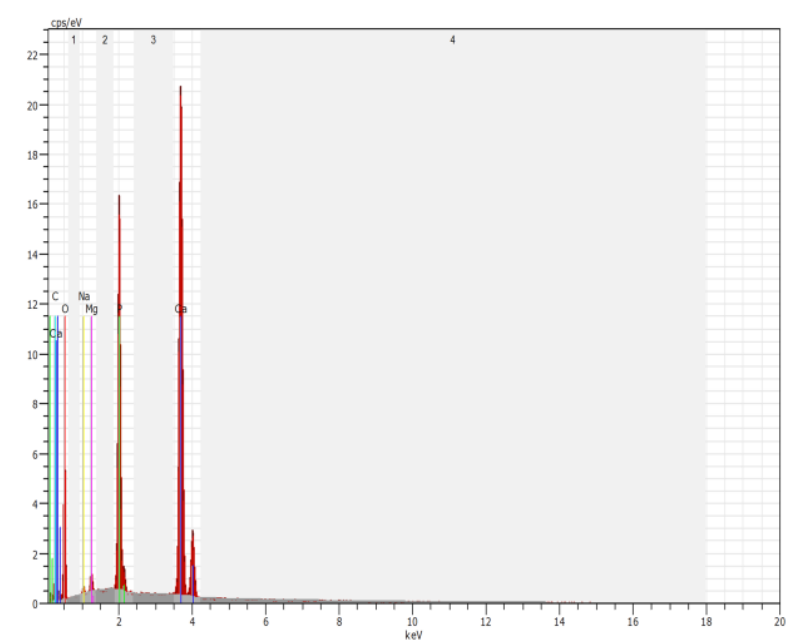

Grafik 3.

Kontrol grubunda koronal bölgede SEM-EDX analizi sonucunda elde edilen bulguları gösteren grafik



Grafik 4.

Kanal tedavili dişler grubunda apikal bölgede SEM-EDX analizi sonucunda elde edilen bulguları gösteren grafik



Grafik 5.

Kanal tedavili dişler grubunda orta üçlüde SEM-EDX analizi sonucunda elde edilen bulguları gösteren grafik

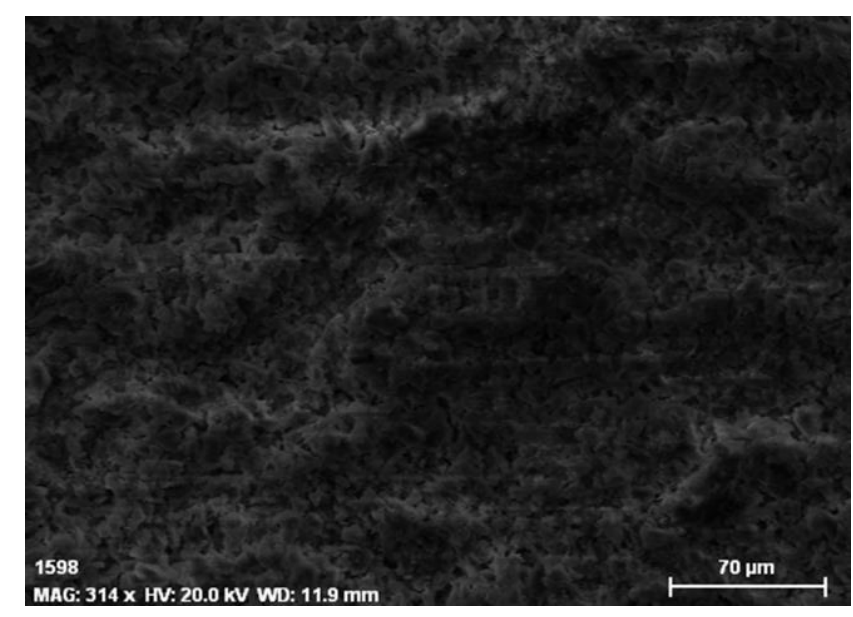

Resim 3.

Grafik 3.'de gösterilen alanın elektron mikroskopta elde edilen görüntüsü $(\times 300)$

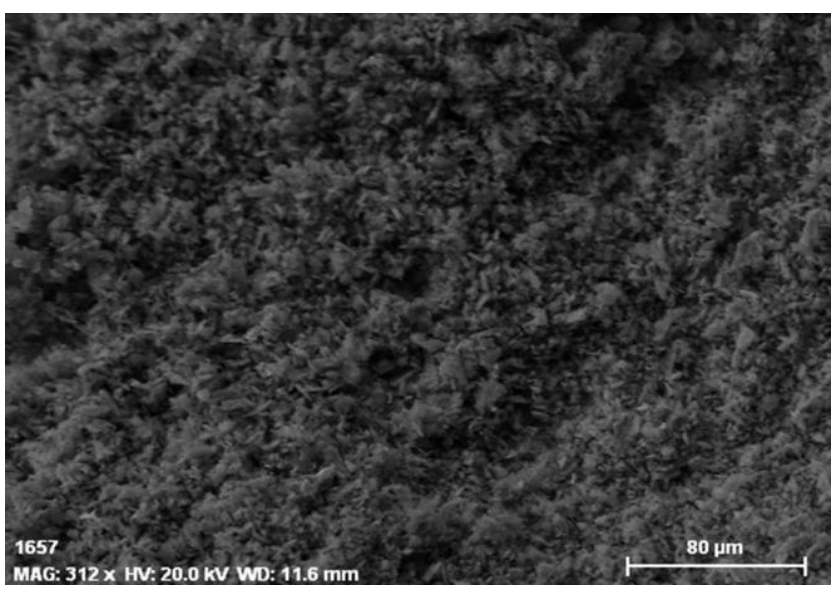

Resim 4.

Grafik 4.'de gösterilen alanın elektron mikroskopta elde edilen görüntüsü $(\times 300)$. Bu görüntü seçilen dişin kök kanalının apikal bölgesinden gutta perka artıkları uzaklaştırıldıktan sonra alınmıştır

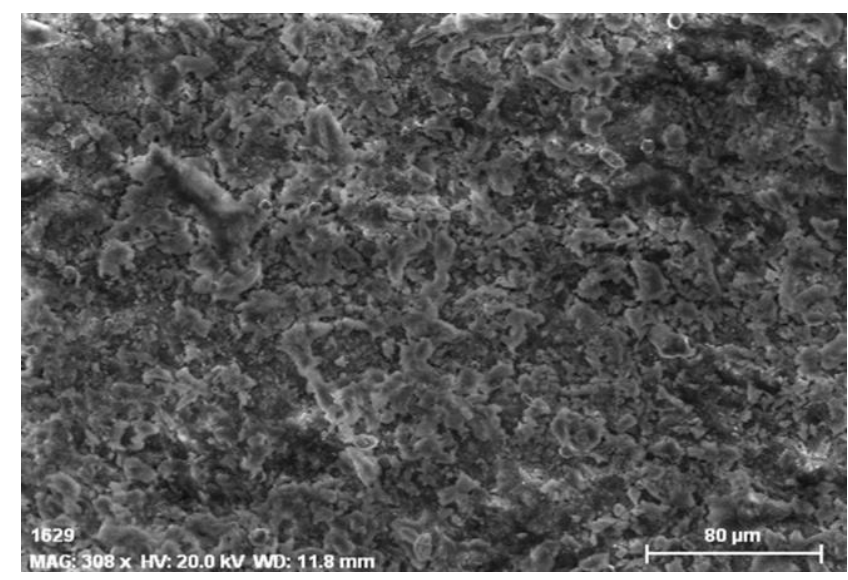

Resim 5.

Grafik 5.'de gösterilen alanın elektron mikroskopta elde edilen görüntüsü $(\times 300)$. Bu görüntü seçilen dişin kök kanalının apikal bölgesinden gutta perka artıkları uzaklaştırıldıktan sonra alınmıştır 


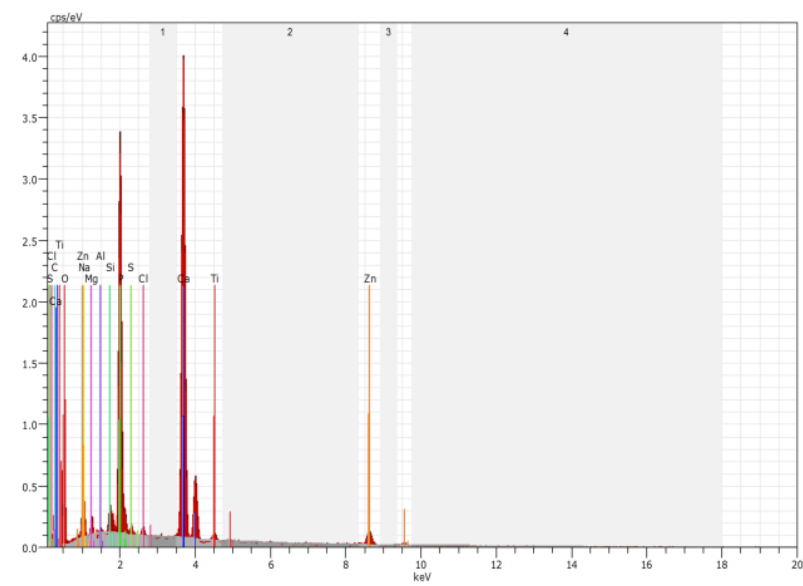

Grafik 6.

Kanal tedavili dişler grubunda koronal bölgede SEM-EDX analizi sonucunda elde edilen bulguları gösteren grafik

\section{Oksijen ile ilgili bulgular}

SEM-EDX analizi sonucunda elde edilen oksijen ile ilgili bulgular Tablo 2'de ve Grafik 7'de verilmiştir. Oksijen miktarı açısından iki grup arasında, iki grubun karşılıklı bölgeleri arasında, her iki grupta da kendi içinde apikal, orta ve koronal bölgeler arasında istatistiksel olarak anlamlı fark bulunamamıştır $(p>0,05)$.

Tablo 2. . Oksijen ile ilgili bulgular

\begin{tabular}{lllll} 
Gruplar & Apikal & Orta & Koronal & Genel \\
\hline $\begin{array}{l}\text { Kanal } \\
\text { Tedavili } \\
\text { Dişler }\end{array}$ & $47,77 \pm 6,874^{\mathrm{a}}$ & $47,78 \pm 5,618^{\mathrm{a}}$ & $48,12 \pm 5,734^{\mathrm{a}}$ & $47,89 \pm 5,999^{\mathrm{a}}$ \\
\hline $\begin{array}{l}\text { Kontrol } \\
\text { Dişler }\end{array}$ & $45,23 \pm 6,765^{\mathrm{a}}$ & $47,17 \pm 3,514^{\mathrm{a}}$ & $45,11 \pm 4,864^{\mathrm{a}}$ & $45,84 \pm 5,219^{\mathrm{a}}$ \\
\hline Genel & $46,50 \pm 6,854$ & $47,48 \pm 4,635$ & $46,61 \pm 5,465$ & $46,87 \pm 5,694$ \\
\hline
\end{tabular}

$\%$ Mean $\pm S D$. Aynı sütundaki veya aynı satırdaki farklı harfler gruplar arası farklılı̆ı göstermektedir.

\section{Karbon ile ilgili bulgular}

SEM-EDX analizi sonucunda elde edilen karbon ile ilgili bulgular Tablo 3'de ve Grafik 8'de verilmiştir. Karbon miktarı, kanal tedavili dişler grubunda kontrol grubuna göre anlamlı derecede yüksek bulunmuştur $(p<0,01)$. İki grubun karşılıklı bölgeleri arasında ve her iki grupta da kendi içinde apikal, orta ve koronal bölgeler açısından fark bulunamamıştır $(p>0,05)$.

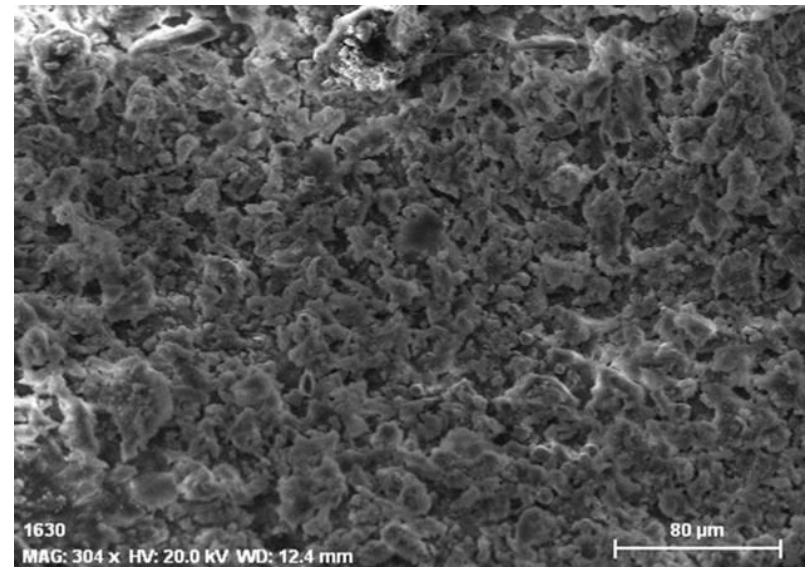

Resim 6.

Grafik 6.'de gösterilen alanın elektron mikroskopta elde edilen görüntüsü $(\times 300)$. Bu görüntü seçilen dişin kök kanalının apikal bölgesinden gutta perka artıkları uzaklaștırıldıktan sonra



Kalsiyum ile ilgili bulgular

SEM-EDX analizi sonucunda elde edilen kalsiyum ile ilgili bulgular Tablo 4'de ve Grafik 9'da verilmiştir. Kalsiyum miktarı, kanal tedavili dişler grubunda kontrol grubuna göre anlamlı derecede düşük bulunmuştur $(p<0,01)$. İki grubun karşılıklı bölgeleri arasında ve her iki grupta da kendi içinde apikal, orta ve koronal bölgeler açısından ise fark bulunamamıştır ( $p>0,05)$. 


\section{Fosfor ile ilgili bulgular}

SEM-EDX analizi sonucunda elde edilen fosfor ile ilgili bulgular Tablo 5'de ve Grafik 10'da verilmiştir. Fosfor miktarı, kanal tedavili dişler grubunda kontrol grubuna göre anlamlı derecede düşük bulunmuştur $(p<0,01)$. İki grubun karşılıklı bölgeleri arasında ve her iki grupta da kendi içinde apikal, orta ve koronal bölgeler açısından ise fark bulunamamıştır $(p>0,05)$.

Tablo 3. Karbon ile ilgili bulgular

\begin{tabular}{lllll|}
\hline Gruplar & Apikal & Orta & Koronal & Genel \\
\hline $\begin{array}{l}\text { Kanal } \\
\begin{array}{l}\text { Tedavili } \\
\text { Dişler }\end{array}\end{array}$ & $15,25 \pm 11,313^{\text {a }}$ & $13,08 \pm 8,314^{\text {a }}$ & $13,53 \pm 8,140^{\text {a }}$ & $13,95 \pm 9,257$ A \\
\hline $\begin{array}{l}\text { Kontrol } \\
\text { Dişler }\end{array}$ & $7,89 \pm 4,248^{\text {a }}$ & $10,01 \pm 6,519^{\text {a }}$ & $9,55 \pm 7,461^{\text {a }}$ & $9,15 \pm 6,187$ B \\
\hline Genel & $11,57 \pm 9,221$ & $11,55 \pm 7,536$ & $11,54 \pm 7,966$ & $11,55 \pm 8,202$ \\
\hline
\end{tabular}

$\%$ Mean $\pm S D$. Aynı sütundaki veya aynı satırdaki farklı harfler gruplar arası farklı̈̆̆ göstermektedir. A,B: $p<0,01$

\section{Tablo 4. Kalsiyum ile ilgili bulgular}

\begin{tabular}{|c|c|c|c|c|}
\hline Gruplar & Apikal & Orta & Koronal & Genel \\
\hline $\begin{array}{l}\text { Kanal } \\
\text { Tedavili } \\
\text { Dişler }\end{array}$ & $22,46 \pm 9,006^{a}$ & $23,5 \pm 8,454^{a}$ & $20,32 \pm 10,867^{a}$ & $22,09 \pm 9,431 \mathrm{~A}$ \\
\hline $\begin{array}{l}\text { Kontrol } \\
\text { Dişler }\end{array}$ & $29,45 \pm 7,390^{a}$ & $\begin{array}{l}26,67 \pm 10,010 \\
\mathrm{a}\end{array}$ & $29,18 \pm 8,460^{a}$ & $28,43 \pm 8,630 B$ \\
\hline Genel & $25,95 \pm 88,680$ & $25,08 \pm 9,285$ & $24,75 \pm 10,607$ & $25,26 \pm 9,548$ \\
\hline
\end{tabular}

$\%$ Mean $\pm S D$. Aynı sütundaki veya aynı satırdaki farklı harfler gruplar arası farkııı̆ı göstermektedir. A,B: $p<0,01$

Tablo 5. Fosfor ile ilgili bulgular

\begin{tabular}{lllll} 
Gruplar & Apikal & Orta & Koronal & Genel \\
\hline $\begin{array}{l}\text { Kanal } \\
\text { Tedavili }\end{array}$ & $9,14 \pm 4,330^{\text {a }}$ & $10,28 \pm 3,252^{\text {a }}$ & $9,24 \pm 3,797^{\text {a }}$ & $9,55 \pm 3,789$ A \\
Dişler & & & & \\
\hline $\begin{array}{l}\text { Kontrol } \\
\text { Dişler }\end{array}$ & $12,05 \pm 2,050^{\text {a }}$ & $11,23 \pm 3,303^{\text {a }}$ & $11,26 \pm 2,982^{\text {a }}$ & $11,52 \pm 2,806$ B \\
\hline Genel & $10,59 \pm 3,654$ & $10,75 \pm 3,272$ & $10,25 \pm 3,521$ & $10,53 \pm 3,463$ \\
\hline
\end{tabular}

$\%$ Mean $\pm S D$. Aynı sütundaki veya aynı satırdaki farklı harfler gruplar arası farklılı̆ı göstermektedir. A,B: $p<0,01$

\section{Magnezyum ile ilgili bulgular}

SEM-EDX analizi sonucunda elde edilen magnezyum ile ilgili bulgular Tablo 6'da ve Grafik 11'de verilmiştir. Magnezyum miktarı açısından iki grup arasında, iki grubun karşııklı bölgeleri arasında, her iki grupta da kendi içinde apikal, orta ve koronal bölgeler açısından istatistiksel olarak anlamlı fark bulunamamıştır $(p>0,05)$.

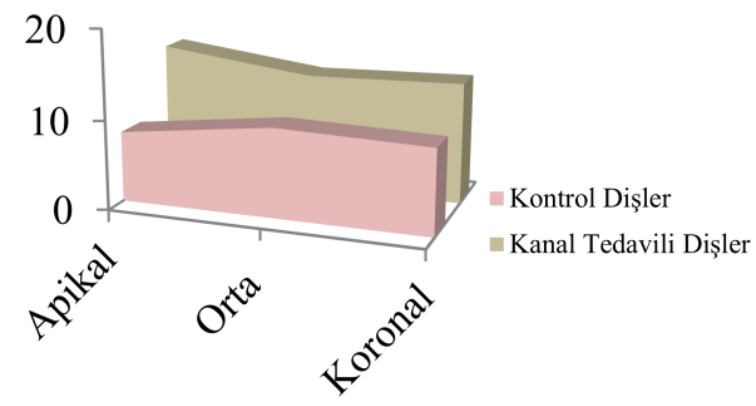

Grafik 8.

SEM-EDX analizi sonucunda elde edilen karbon ile ilgili bulguları gösteren alan grafiği



Grafik 9.

SEM-EDX analizi sonucunda elde edilen kalsiyum ile ilgili bulguları gösteren alan grafiği

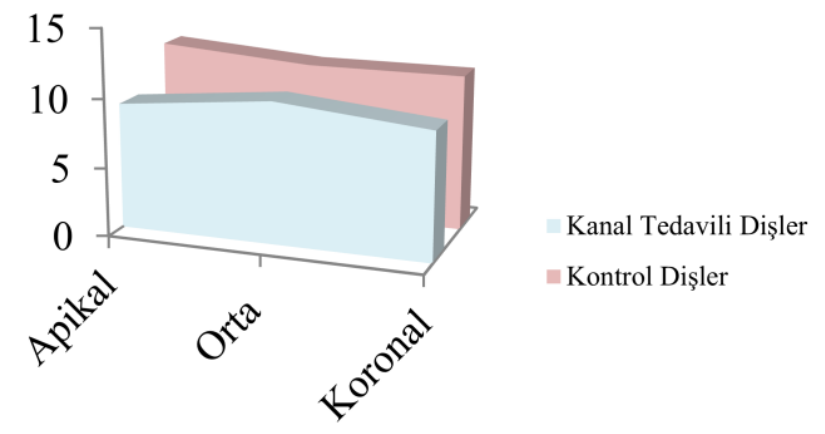

Grafik 10.

SEM-EDX analizi sonucunda elde edilen fosfor ile ilgili bulguları gösteren alan grafiği 
Tablo 6. Magnezyum ile ilgili bulgular

\begin{tabular}{lllll} 
Gruplar & Apikal & Orta & Koronal & Genel \\
\hline $\begin{array}{l}\text { Kanal } \\
\begin{array}{l}\text { Tedavili } \\
\text { Dişler }\end{array}\end{array}$ & $\begin{array}{l}0,7215 \pm 0,393 \\
\text { a }\end{array}$ & $\begin{array}{l}0,8010 \pm 0,322 \\
a^{\prime}\end{array}$ & $0,717 \pm 0,440^{a}$ & $0,7465 \pm 0,383^{a}$ \\
\hline $\begin{array}{l}\text { Kontrol } \\
\text { Dişler }\end{array}$ & $0,8210 \pm 0,247$ & $\begin{array}{l}0,86953 \pm 0,296 \\
a^{a}\end{array}$ & $0,8965 \pm 0,280^{a}$ & $0,8623 \pm 0,272^{a}$ \\
\hline Genel & $0,7713 \pm 0,328$ & $0,8353 \pm 0,307$ & $0,8068 \pm 0,375$ & $0,8044 \pm 0,336$ \\
\hline
\end{tabular}

$\%$ Mean $\pm S D$. Aynı sütundaki veya aynı satırdaki farklı harfler gruplar arası farklılı̆̆ı göstermektedir

\section{Sodyum ile ilgili bulgular}

SEM-EDX analizi sonucunda elde edilen sodyum ile ilgili bulgular Tablo 7'de ve Grafik 12'de verilmiştir. Sodyum miktarı açısından iki grup arasında, iki grubun karşılıklı bölgeleri arasında ve her iki grupta da kendi içinde apikal, orta ve koronal bölgeler açısından istatistiksel olarak anlamlı fark bulunamamıştır $(p>0,05)$.

Tablo 7. Sodyum ile ilgili bulgular

\begin{tabular}{lllll} 
Gruplar & Apikal & Orta & Koronal & Genel \\
\hline $\begin{array}{l}\text { Kanal } \\
\text { Tedavili } \\
\text { Dişler }\end{array}$ & $0,809 \pm 0,486^{a}$ & $0,948 \pm 0,513^{a}$ & $1,085 \pm 0,751^{a}$ & $0,947 \pm 0,596^{a}$ \\
\hline $\begin{array}{l}\text { Kontrol } \\
\text { Dişler }\end{array}$ & $1,059 \pm 1,560^{a}$ & $1,213 \pm 1,038^{a}$ & $0,993 \pm 1,271^{a}$ & $1,088 \pm 1,628^{a}$ \\
\hline Genel & $0,934 \pm 1,148$ & $1,080 \pm 1,473$ & $1,039 \pm 1,031$ & $1,018 \pm 1,223$ \\
\hline
\end{tabular}

$\%$ Mean $\pm S D$. Aynı sütundaki veya aynı satırdaki farklı harfler gruplar arası farklılı̆ı göstermektedir

Tablo 8. Sülfür ile ilgili bulgular

\begin{tabular}{lllll|} 
Gruplar & Apikal & Orta & Koronal & Genel \\
\hline $\begin{array}{l}\text { Kanal } \\
\begin{array}{l}\text { Tedavili } \\
\text { Dişler }\end{array}\end{array}$ & $\begin{array}{l}0,6000 \pm 0,970 \\
\text { a }\end{array}$ & $\begin{array}{l}0,6250 \pm 1,095 \\
\text { a }\end{array}$ & $0,8800 \pm 1,350^{a}$ & $0,7017 \pm 1,137^{a}$ \\
\hline $\begin{array}{l}\text { Kontrol } \\
\text { Dişler }\end{array}$ & $0,7450 \pm 3,081$ & $\begin{array}{l}0,3690 \pm 1,138 \\
\text { a }\end{array}$ & $0,5520 \pm 1,968^{a}$ & $0,5553 \pm 2,178^{a}$ \\
\hline Genel & $0,6725 \pm 2,256$ & $0,4970 \pm 1,110$ & $0,7160 \pm 1,674$ & $0,6285 \pm 1,732$ \\
\hline
\end{tabular}

$\%$ Mean $\pm S D$. Aynı sütundaki veya aynı satırdaki farklı harfler gruplar arası farklılığı göstermektedir



\section{Sülfür ile ilgili bulgular}

SEM-EDX analizi sonucunda elde edilen sülfür ile ilgili bulgular Tablo 8'de ve Grafik 13'de verilmiştir. Sülfür miktarı açısından iki grup arasında, iki grubun karşılıklı bölgeleri arasında ve her iki grupta da kendi içinde apikal, orta ve koronal bölgeler açısından istatistiksel olarak anlamlı fark bulunamamıştır ( $p>0,05)$.

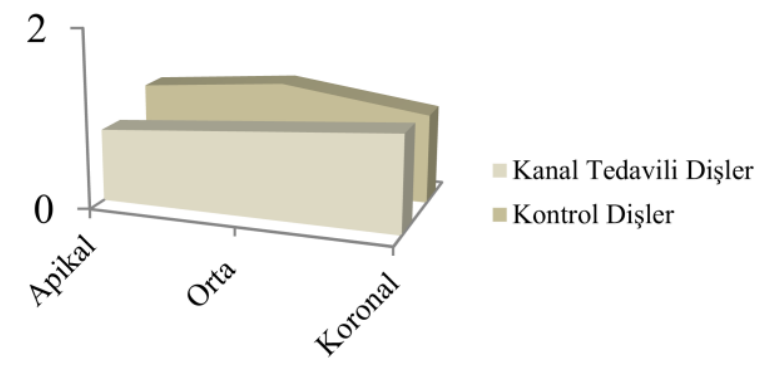

Grafik 12.

SEM-EDX analizi sonucunda elde edilen sodyum ile ilgili bulguları gösteren alan grafiği



Grafik 13.

SEM-EDX analizi sonucunda elde edilen sülfür ile ilgili bulguları gösteren alan grafiği 


\section{Çinko ile ilgili bulgular}

SEM-EDX analizi sonucunda elde edilen çinko ile ilgili bulgular Tablo 9'de ve Grafik 14'de verilmiştir. Çinko miktarı açısından iki grup arasında, iki grubun karşılıklı bölgeleri arasında ve her iki grupta da kendi içinde apikal, orta ve koronal bölgeler açısından istatistiksel olarak anlamlı fark bulunamamıştır $(p>0,05)$.

\section{Tablo 9. Çinko ile ilgili bulgular}

\begin{tabular}{|c|c|c|c|c|}
\hline Gruplar & Apikal & Orta & Koronal & Genel \\
\hline $\begin{array}{l}\text { Kanal } \\
\text { Tedavili } \\
\text { Dişler }\end{array}$ & $1,414 \pm 2,312^{a}$ & $1,941 \pm 3,981^{a}$ & $4,148 \pm 6,843^{a}$ & $2,501 \pm 4,830^{a}$ \\
\hline $\begin{array}{l}\text { Kontrol } \\
\text { Dişler }\end{array}$ & $1,666 \pm 6,782^{a}$ & $1,390 \pm 3,940^{a}$ & $0,931 \pm 3,432^{a}$ & $1,329 \pm 4,868^{a}$ \\
\hline Genel & $1,540 \pm 5,003$ & $1,665 \pm 3,919$ & $2,539 \pm 5,586$ & $1,915 \pm 4,864$ \\
\hline
\end{tabular}

$\%$ Mean $\pm S D$. Aynı sütundaki veya aynı satırdaki farklı harfler gruplar arası farklıığı göstermektedir

Tablo 10. Alüminyum ile ilgili bulgular

\begin{tabular}{lllll} 
Gruplar & Apikal & Orta & Koronal & Genel \\
\hline $\begin{array}{l}\text { Kanal } \\
\begin{array}{l}\text { Tedavili } \\
\text { Dişler }\end{array}\end{array}$ & $0,1465 \pm 0,273$ & $0,1065 \pm 0,183$ & $0,1100 \pm 0,197^{a}$ & $0,1210 \pm 0,218$ A \\
\hline $\begin{array}{l}\text { Kontrol } \\
\text { Dişler }\end{array}$ & $0,0450 \pm 0,074$ & $\begin{array}{l}0,0300 \pm 0,093 \\
\text { a }\end{array}$ & $0,0425 \pm 0,074^{a}$ & $0,0391 \pm 0,0800$ B \\
\hline Genel & $0,0957 \pm 0,204$ & $0,0682 \pm 0,148$ & $0,0762 \pm 0,151$ & $0,0800 \pm 0,169$ \\
\hline
\end{tabular}

$\%$ Mean $\pm S D$. Aynı sütundaki veya aynı satırdaki farklı harfler gruplar arası farklılı̆ı göstermektedir. $A, B: p<0,01$

\section{Klor ile ilgili bulgular}

SEM-EDX analizi sonucunda elde edilen klor ile ilgili bulgular Tablo 11'de ve Grafik 16'da verilmiştir. Klor miktarı, kanal tedavili dişler grubunda kontrol grubuna göre anlamlı derecede yüksek bulunmuştur $(p<0,01)$. İki grubun karşılıklı bölgeleri arasında ve her iki grupta kendi içinde apikal, orta ve koronal bölgeler açısından istatistiksel olarak anlamlı fark bulunamamıştır ( $p>0,05)$.

\section{Alüminyum ile ilgili bulgular}

SEM-EDX analizi sonucunda elde edilen alüminyum ile ilgili bulgular Tablo 10'da ve Grafik 15'de verilmiştir. Alüminyum miktarı, kanal tedavili dişler grubunda kontrol grubuna göre anlamlı derecede yüksek bulunmuştur $(p<0,01)$. İki grubun karşılıklı bölgeleri arasında ve her iki grupta da kendi içinde apikal, orta ve koronal bölgeler açısından istatistiksel olarak anlamlı fark bulunamamıştır $(p>0,05)$.



Grafik 14.

SEM-EDX analizi sonucunda elde edilen çinko ile ilgili bulguları gösteren alan grafiği

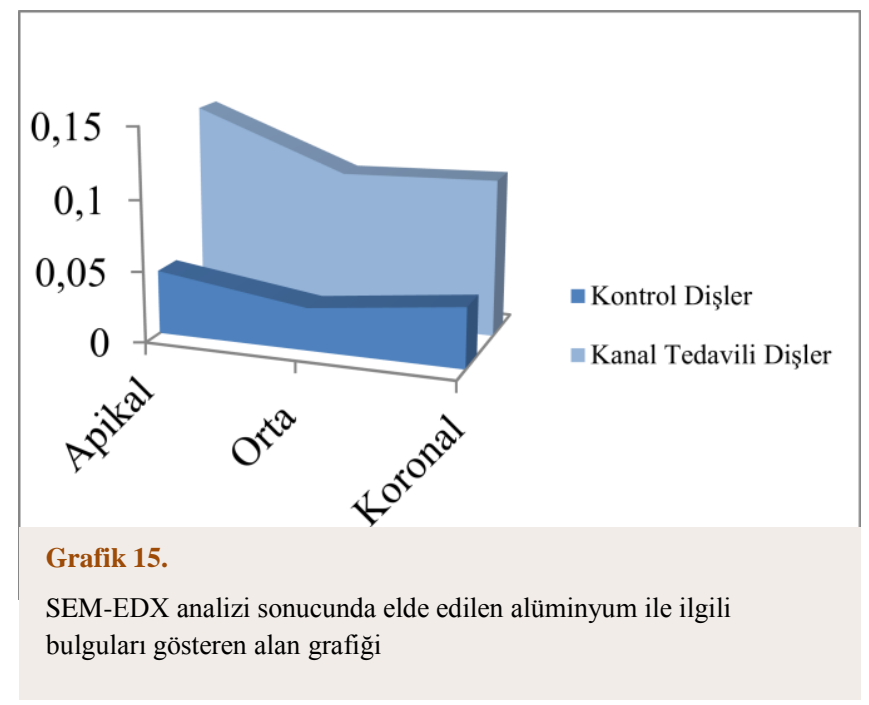

\section{$\mathrm{Ca} / \mathrm{P}$ ile ilgili bulgular}

SEM-EDX analizi sonucunda elde edilen $\mathrm{Ca} / \mathrm{P}$ ile ilgili bulgular Tablo 12'de ve Grafik 17'de verilmiştir. Ca/P miktarı açısından iki grup arasında, iki grubun karşılıklı bölgeleri arasında ve her iki grupta kendi içinde apikal, orta ve koronal bölgeler açısından istatistiksel olarak anlamlı fark bulunamamıştır ( $p>0,05)$. 
Tablo 11. Klor ile ilgili bulgular

\begin{tabular}{lllll} 
Gruplar & Apikal & Orta & Koronal & Genel \\
\hline $\begin{array}{l}\text { Kanal } \\
\begin{array}{l}\text { Tedavili } \\
\text { Dişler }\end{array}\end{array}$ & $0,3285 \pm 0,676^{a}$ & $0,1720 \pm 0,322^{a}$ & $0,1925 \pm 0,296^{a}$ & $0,2310 \pm 0,462$ A \\
\hline $\begin{array}{l}\text { Kontrol } \\
\text { Dişler }\end{array}$ & $0,0520 \pm 0,099^{a}$ & $0,0325 \pm 0,091^{a}$ & $0,0705 \pm 0,126^{a}$ & $0,0517 \pm 0,105$ B \\
\hline Genel & $0,1902 \pm 0,497$ & $0,1022 \pm 0,244$ & $0,1315 \pm 0,233$ & $0,1413 \pm 0,346$ \\
\hline
\end{tabular}

$\%$ Mean $\pm S D$. Aynı sütundaki veya aynı satırdaki farklı harfler gruplar arası farkıı̆̆ı göstermektedir. A,B: $p<0,01$

Tablo 12. Ca/P ile ilgili bulgular

\begin{tabular}{lllll} 
Gruplar & Apikal & Orta & Koronal & Genel \\
\hline $\begin{array}{l}\text { Kanal } \\
\begin{array}{l}\text { Tedavili } \\
\text { Dişler }\end{array}\end{array}$ & $3,121 \pm 2,625^{a}$ & $2,292 \pm 0,406^{a}$ & $2,147 \pm 0,667^{a}$ & $2,520 \pm 1,613^{a}$ \\
\hline $\begin{array}{l}\text { Kontrol } \\
\text { Dişler }\end{array}$ & $2,409 \pm 0,417^{a}$ & $2,341 \pm 0,527^{a}$ & $2,875 \pm 2,105^{a}$ & $2,542 \pm 1,277^{a}$ \\
\hline Genel & $2,765 \pm 1,890$ & $2,316 \pm 0,465$ & $2,511 \pm 1,585$ & $2,531 \pm 1,449$ \\
\hline
\end{tabular}

$\%$ Mean $\pm S D$. Aynı sütundaki veya aynı satırdaki farklı harfler gruplar arası farklıı̆ı göstermektedir

\section{TARTIŞMA}

$\mathrm{Bu}$ çalışmada kök kanal tedavisi görmüş ve kontrol grubundaki dişlerin kanal dentin içeriğinin elementel analizi SEM-EDX yöntemi kullanılarak yapılmıştır. Çalışmamızda bu tekniğin seçilmesinin nedeni, istenilen alan ve derinlikte elementel haritalama yapmaya izin vermesidir (Gandolfi ve ark 2010). Bu şekilde kök kanalından istenilen bölge seçilerek hem yüzeysel görüntü alınabilmekte hem de elementel haritalama yapılabilmektedir. Haritalamada elementlerin nispi dağılımı belirlenebilmektedir. Dolayısıyla belli bölgelerde homojen bir dağılım olmasa bile genel ortalama değerler hesaplanabileceğinden çok daha doğru ve güvenilir sonuçlar elde edileceği için çalışmamızda SEM-EDX yönteminin kullanılmasına karar verilmiştir.

Kök kanal tedavisi sırasında kullanılan irrigasyon solüsyonlarının kök dentini ve koronal dentin ile temas halinde olması sebebiyle, kanal dolgu materyalinin ve/veya üst restorasyon materyalinin diş dokularına bağlanması etkilenebilmektedir (Rotstein ve ark. 1996) ve bu durum koronal sızıntıya sebep olmaktadır (Saleh ve Ettman 1999). Koronal sızıntının, endodontik tedavide, başarısızlığın önemli bir sebebi olabileceği belirtilmiştir (Saunders

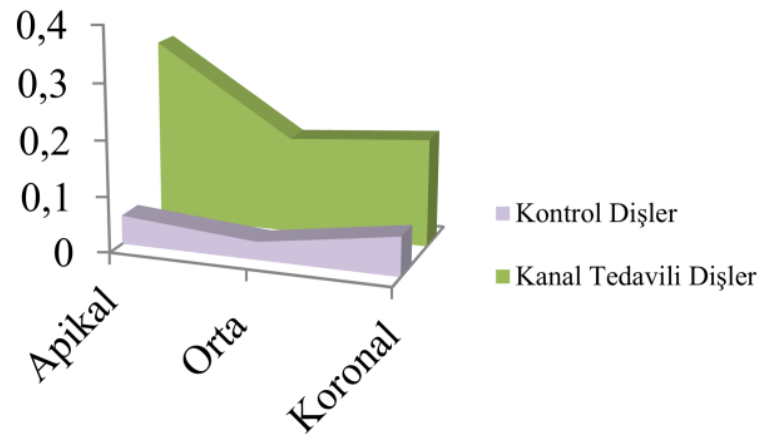

Grafik 16 .

SEM-EDX analizi sonucunda elde edilen klor ile ilgili bulguları gösteren alan grafiği

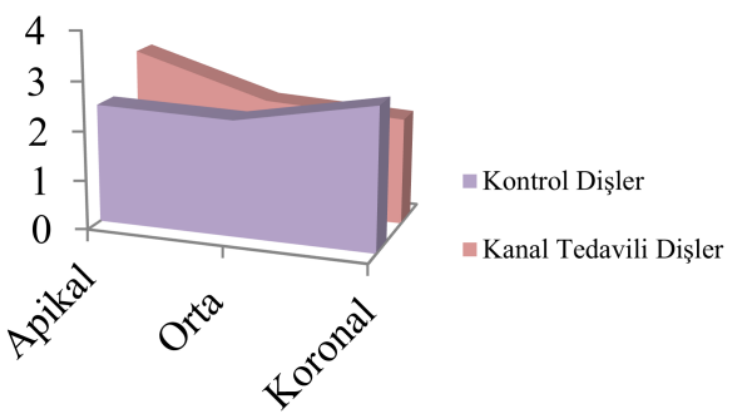

Grafik 17 .

SEM-EDX analizi sonucunda elde edilen $\mathrm{Ca} / \mathrm{P}$ ile ilgili bulguları gösteren alan grafiği

ve Saunders 1994, Cobankara ve ark 2004).

Kök kanal tedavisi sırasında kullanılan irrigasyon solüsyonları ve şelasyon ajanlarının dentinde oluşturduğu erozyonun oluşma mekanizmasının, dentinin yapısıyla ilişkili olduğu düşünülmektedir. Dentin, hidroksiapatit ile sarılmış yoğun kollajen ağ içermektedir (Di Renzo ve ark. 2001). Kök kanal tedavisinde en çok kullanılan irrigasyon solüsyonlarından biri olan $\mathrm{NaOCl}$, güçlü yapıda, spesifik olmayan oksitleyici bir ajandır. Aminoasitler ile nötralizasyon ve klorlama yoluyla reaksiyona girer ve aminoasitleri ayrıştırır (Qian ve ark. 2011). İmmünohistokimyasal bir çalışmada (Oyarzun ve ark. 2002), $\mathrm{NaOCl}$ uygulamasından sonra kök dentininde tip 1 kollajenin ve glikozaminoglikanın immün reaktivitesini kaybettiği bildirilmiştir. Çapar ve Aydınbelge (2013) farklı irrigasyon aktivasyon protokollerini karşılaştırdıkları çalışmalarında, sadece SAF ve Endoaktivatör uygulamasının dentindeki $\mathrm{Ca} / \mathrm{P}$ oranını değiştirdiğini, diğer aktivasyon protokollerinin ise 
dentinde $\mathrm{Ca}, \mathrm{P}, \mathrm{Mg}$ ve $\mathrm{S}$ mineralleri açısından anlamlı bir değişikliğine sebep olmadığını bulmuşlardır.

İyi bilinen bir şelasyon ajanı olan EDTA, sadece Ca iyonlarına etki etmekle kalmayıp, dentinde 'mineralsiz' alanlar denilen demineralizasyon lezyonları oluşturmaktadır (Kawasaki ve ark. 1999). Tek başına kullanıldığında, $\mathrm{NaOCl}$, konsantrasyona bağlı olarak (Arı ve Erdemir 2005) dentinde Ca/P oranını azaltabilir (Rotstein ve ark. 1996) veya artırabilir (Doğan ve Çalt 2001). NaOCl, EDTA'dan önce kullanıldığında, kollajen fibrillerin NaOCl'nin çözücü etkisinden hidroksiapatit tabaka ile korunduğu; ancak EDTA, EGTA veya sitrik asitten sonra kullanıldığında ise, demineralizasyon ajanları tarafından açığa çıkarılmış halde olan kollajen fibrillere direkt olarak etkidiği bildirilmiştir (Qian ve ark. 2011). Bu sonuçlara göre takip eden $\mathrm{NaOCl}$ uygulamasının demineralize edici etkiyi artırabileceği söylenebilir (Doğan ve Çalt 2001, Perdiago ve ark. 2001).

Ayrıca, Borges ve ark (Borges ve ark. 2012), farklı kanal dolgu materyallerini kullandıkları çalışmalarında, $\mathrm{Ca}, \mathrm{Na}, \mathrm{K}, \mathrm{Zn}, \mathrm{C}, \mathrm{Zr}, \mathrm{O}, \mathrm{Bi}, \mathrm{Si}$ gibi bazı elementlerin miktarlarında azalma olduğunu bildirmişlerdir. Bu sebeplerle kök kanal tedavisi sırasında kullanılan irrigasyon solüsyonları, şelasyon ajanları ve/veya kanal dolgu patlarının dentin içeriği üzerinde ve tedavinin başarısında önemli bir yeri vardır (Akman ve ark. 2016). Ayrıca şu da iyi bilinmektedir ki, sert dokuda bulunan mineral içeriğin oranı dişin dayanıklılığı ve elastisite modülüne önemli ölçüde katkıda bulunmaktadır. Tedavi sırasında kullanılan solüsyonların yol açtığı erozyonun derinliği, kök kalınlığı ve kökteki sklerotik dentin miktarı dikey kök kırığı oluşumunda tetikleyici bir faktör olarak rol oynayabilmektedir (Qian ve ark. 2011).

Sayın ve ark. (2007), \%17 EDTA ve \%2,5 NaOCl'nin birlikte bir dakika uygulamasının, tek başına \%17 EDTA uygulamasına göre kök dentininden daha fazla Ca kaybına neden olduğunu bulmuştur. Sayın ve ark (2009)'nın başka bir çalışmasında, artan zaman aralıklarında IKI ve NaOCl'nin kök dentininden $\mathrm{Ca}$ salınım miktarını arttığı, CHX'in ise en yüksek $\mathrm{Ca}$ salınım oranının 10. dakikada ve MTAD'nin ise 5. dakikada görüldüğü bildirilmiştir. Akman ve ark. (2016) çalışmasında, borik asit, EDTA ve sitrik asitin kök dentininin mineral içeriğine olan etkisi araştırımış: Borik asit uygulamasının kök dentininin $\mathrm{O}, \mathrm{Na}, \mathrm{K}$ ve $\mathrm{Ca} / \mathrm{P}$ oranını anlamlı derecede artırdığı ve $\mathrm{Ca}, \mathrm{C}, \mathrm{Mg}$ mineral içeriğini değiştirmediği; EDTA uygulamasının $\mathrm{O}, \mathrm{Na}, \mathrm{C}, \mathrm{Ca} / \mathrm{P}$ oranını anlamlı derecede artırdığı ve $\mathrm{Ca}, \mathrm{P}, \mathrm{S}$ mineral içeriğini ise anlamlı derecede azalttığı; sitrik asit uygulamasının $\mathrm{C}, \mathrm{Na}, \mathrm{Ca} / \mathrm{P}$ oranını artırdığı ve
Ca, P, S mineral içeriğini azalttığı bildirilmiştir. Bu irrigasyon solüsyonlarının ve şelasyon ajanlarının dekalsifiye edici etkisi uygulama zamanına, solüsyonun türüne, kök kanalında ulaşılabilen miktarına, solüsyonun $\mathrm{pH}$ ve konsantrasyonuna, kombine veya tek başına kullanılmasına bağlı olarak değişmektedir (Sayın ve ark. 2007, Doğan ve Çalt 2001, Perez-Heredeia ve ark. 2008, Akman ve ark. 2016).

Mevcut çalışmada kök kanal tedavisi görmüş grup ve kontrol grubu arasında $\mathrm{O} 2$ miktarı açısından fark bulunamazken $(p>0.05)$, C miktarı açısından anlamlı fark bulunmuştur $(p<0.01)$. Kanal tedavili dişlerde $C$ miktarı kontrol gruba göre daha yüksektir. Çalışmamızın sonuçlarına göre, kök kanal tedavisi görmüş grup ve kontrol grubu arasında kalsiyum miktarı açısından da anlamlı fark bulunmuştur $(p<0.01)$. Kanal tedavisi yapılan grupta kontrol grubuna göre $\mathrm{Ca}$ oranında anlamlı bir azalma gözlenmiştir. Bulgularımızı destekler şekilde, başka çalışmalarda da NaOCl'nin kök dentinindeki $\mathrm{Ca}$ miktarını azalttığı gösterilmiştir (Doğan ve Çalt 2001, Sayın ve ark 2007, Perez-Heredeia ve ark 2008). Spano ve ark'nın (2009) tam tersine, Zehnder ve ark (2005), \%10'luk sitrik asit solüsyonunun \%15,5'lik EDTA solüsyonuna göre kalsiyum miktarını önemli ölçüde azalttığını bulmuştur. Başka bir çalışmada (Sayın ve ark 2007), EDTA kullanımının, dentin de dâhil olmak üzere, mineral dokudaki Ca miktarını azalttığını bildirmişlerdir. Çobankara ve ark (2011), çalışmalarında EDTA, sitrik asit ve paresetik asit kullanımı sonucunda $\mathrm{Ca}$ oranının önemli ölçüde azaldığını bulmuştur. Arı ve Erdemir (2005), uyguladıkları irrigasyon solüsyonlarından sonra $\mathrm{Ca}$ ve P oranında anlamlı bir değişiklik gözlemiş ve \%5,25 $\mathrm{NaOCl}$ uygulamasından sonra görülen $\mathrm{Ca}$ miktarındaki düşüşü istatistiksel olarak anlamlı bulmamışlardır. Bu çalışmaların sonuçları bizim bulgularımızla uyumludur. Ca oranındaki düşüşün sebebi kök kanal tedavisi sırasında kullanılan irrigasyon solüsyonları ile ilişkili olabilir. Ancak bu çalışmada, kanal tedavili dişler grubunu, önceden kanal tedavisi görmüş dişler arasından çekim endikasyonu konulan dişlerin oluşturduğu unutulmamalıdır. Bu dişlerdeki kanal tedavilerinin nerede ve nasıl yapıldığı, yapılırken hangi solüsyonların ne kadar süre, hangi miktarda, hangi solüsyonlarla birlikte kullanıldığı ve/veya tedavi esnasında hangi kanal dolgu patının kullanıldığı tam olarak bilinememektedir. Kanal tedavileri yapıldığı zamandan itibaren, analiz zamanına kadar geçen süreler arasında farklılıklar mevcuttur. Ayrıca bu dişlerden bazıları çalışmaya katılmadan önce retreatment tedavisi görmüştür. Bu tedavi sırasında kullanılan gutta perka çözücülerinin de $\mathrm{Ca}$ oranındaki düşüşün sebepleri arasında olabileceği düşünülebilir (Erdemir ve ark 2004). Tüm bunlar, bizim çalışmamızın limitasyonları arasında yer almaktadır. Ca oranındaki düşüşü destekleyen çalışmaların aksine, Altundaşar ve 
ark. (2006), lazer uygulanan gruplarda $\mathrm{Ca}$ ve $\mathrm{P}$ oranında artış gözlemiş ve lazer uygulaması sırasında organik komponentin buharlaşmasının yüzeysel dentinde $\mathrm{Ca}$ ve $\mathrm{P}$ oranında artışa sebep olmuş olabileceğini bildirmişlerdir.

Çalışmamızın sonucunda, Arı ve Erdemir (2005) ile benzer şekilde, kök kanal tedavili dişlerde kontrol dişlere göre $P$ oranında anlamlı bir düşüş bulunmuştur $(p<0.01)$. Hennequin ve Douillard'ın (1995) çalışmalarında da sitrik asit uygulaması sonucunda $\mathrm{Ca}$ ve $P$ miktarında azalma gözlenmiştir. Bu bulgulardan farklı olarak, Altundaşar ve ark. (2006) çalışmasında Rc-Prep ve \%5,25 NaOCl grubu ile, Er,Cr:YSGG lazer ve $\% 5,25 \mathrm{NaOCl}$ gruplarında $P$ miktarı, kontrol grubuna göre daha yüksek bulunmuştur. Topçuoğlu ve Köseoğlu (2015)' nun çalışmasında Er:YAG ve Nd:YAG lazer uygulaması sonucunda, kök dentininde $\mathrm{Ca}, \mathrm{P}, \mathrm{Mg}, \mathrm{Ca}$, and $\mathrm{K}$ miktarında ve $\mathrm{Ca} / \mathrm{P}$ oranında anlamlı bir farklııı bulunamamıştır. Bu sonuçlar arası farklııklar çalışmalarda kullanılan solüsyonların konsantrasyonlarının, uygulama yöntemlerinin ve sürelerinin ve/veya ölçümde kullanılan tekniklerin farklı olmasından kaynaklanabilir. Nitekim Altundaşar ve ark. (2006), diğer çalışmalardan farklı olan sonuçlarını lazer uygulaması sırasında organik komponentin buharlaşmasının yüzeysel dentinde $\mathrm{Ca}$ ve $\mathrm{P}$ oranında artışa ve SEM-EDX tekniğinde $\mathrm{Ca}$ ve $\mathrm{P}$ ölçümlerinin oldukça hassas olmasına bağlamışlardır.

Mevcut çalışmada, gruplar arasında $\mathrm{Ca} / \mathrm{P}$ oranında farklılık bulunamamıştır. Altundaşar ve ark. (2006) ile Topçuoğlu ve Köseoğlu (2015)'nun sonuçları da bizim sonuçlarımıza benzer şekildedir. Bulgularımızın aksine Doğan ve Çalt'ın (2001)çalışmasında \%2,5 NaOCl ve $\% 2,5 \mathrm{NaOCl}$ ile \%17 EDTA'nın kombine kullanıldığı gruplarda $\mathrm{Ca} / \mathrm{P}$ oranında anlamlı azalma bulunmuştur. Arı ve Erdemir (2005), Hennequin ve ark. (1994) bulguları da bu sonucu destekler niteliktedir. Çobankara ve ark. (2011), parasetik asit uygulanan grupta $\mathrm{Ca} / \mathrm{P}$ miktarında anlamlı azalma gözlemişlerdir. Gürbüz ve ark. (2008)'nın sonuçlarına göre, $\mathrm{NaOCl}$ uygulamasının ardından dentinde $\mathrm{Ca}$ ve $\mathrm{Ca} / \mathrm{P}$ oranında anlamlı bir düşüş gözlenmiştir. Bu bulgulardan farklı olarak, Doğan ve Çalt (2001), NaOCI uygulamasından sonra $\mathrm{Ca} / \mathrm{P}$ oranında anlamlı bir artış gözlemiş, bu sonucu $\mathrm{NaOCl}$ uygulamasından sonra ortaya çıkan inorganik yapının, dentinin çözünmesini önlemesine ve organik yapının çözünmesiyle dentin duvarında smear tabakası oluşumuna bağlamışlardır. Bizim çalışmamız sonucunda $\mathrm{Ca} / \mathrm{P}$ oranında değişiklik gözlenmemesinin sebebi, kullanılan solüsyonlar ile irrite olmuş tabakadaki kimyasal değişikliğin sınırlarının yüzeysel düzeyde kalması ile ilişkili olabilir.

Ca ve P'ın yanında, Mg da mineralize dokularda her zaman bulunan bir elementtir ve mineralizasyon sürecini, özellikle kristal büyümeyi etkilemektedir (Arı ve Erdemir 2005, Wiesmann ve ark. 1997). Çalışmamızın sonuçlarına göre, Mg miktarı açısından anlamlı bir fark bulunamamıştır $(p>0,05)$. Bizim bulgularımızı destekler şekilde, Hennequin ve ark. (1995), sitrik asit uygulaması sonucunda Mg miktarında bir değişiklik gözlememişlerdir. Aynı şekilde Arı ve Erdemir'in (2005) çalışmasında da, Mg miktarında farklılık bulunamamıştır. Bizim sonucumuzdan farklı olarak Doğan ve Çalt'ın (2001) çalışmasında $\mathrm{NaOCl}$ ile kombine şelasyon ajanı kullanımı sonucunda Mg miktarında anlamlı bir artış gözlenmiştir. Yine benzer şekilde Altundaşar ve ark. (2006) çalışmasında Rc-Prep ve \%5,25 NaOCl; Er,Cr:YSGG lazer ve \%5,25 $\mathrm{NaOCl}$ uygulanan gruplarda Mg miktarında anlamlı bir artış görülmüştür. Tüm sonuçlardan farklı bir şekilde Sakae ve ark. (1998) çalışmasında $\mathrm{NaOCl}$ kullanımı sonucunda Mg miktarında azalma görülmüştür. Çobankara ve ark. (2011) çalışmasında da parasetik asit kullanımı sonucunda Mg miktarında anlamlı bir azalma gözlenmiştir.

Mevcut çalışmanın sonuçlarına göre $\mathrm{Na}, \mathrm{S}, \mathrm{Zn}, \mathrm{Ag}$ miktarı açsından gruplar arası farklıık bulunamamıştır $(p>0,05)$. Arı ve Erdemir (2005) çalışmasında $K$ ve $S$ miktarı açısından fark bulunamamıştır. Çobankara ve ark. (2011), parasetik asit kullanımı sonucunda P, K, $\mathrm{Na}$ ve $\mathrm{S}$ oranlarının önemli ölçüde azaldığını bulmuşlardır. Bizim çalışmamızın sonuçlarına göre Al ve $\mathrm{Cl}$ miktarında kontrol grubuna göre anlamlı bir artış gözlenmiştir. Sülfür, proteoglikanlar için bir belirteçtir ve sert dokuların yapısında da bulunmaktadır. Bu mineralin miktarındaki değişiklikler organik matriksin hasara uğramasına neden olmaktadır (Arı ve Erdemir 2005). Bu çalışmada, sülfür miktarında açısından anlamlı bir fark bulunamamıştır.

Kang ve ark. (2004), diş dokusunun mineral içeriğinin dişin farklı bölgelerinde farklı yoğunlukta bulunduğunu bildirmelerine rağmen, bizim çalışmamızın sonuçlarına göre her iki grubun kendi içinde veya iki grup arasında diş dokusunun apikal, orta ve koronal bölgelerinde mineral içerik açısından fark bulunamamıştır $(p<0.05)$. Bizim bulgularımızla uyumlu olarak Hennequin ve ark. (1994) da çalışmalarında, kök kanalını 3 ayrı noktadan incelenmiş, apikal orta ve koronal bölgeler arasında Ca ve $\mathrm{P}$ miktarı açısından farklılık bulamamışlardır.

$\mathrm{Bu}$ sonuçlar arasındaki farklılıklar, çalışmalarda kullanılan materyal ve yöntem farklılıklarıyla ilişkili olabilir. Bu sonuçların daha ayrıntılı bir şekilde açıklanabilmesi, daha hassas ve güçlü sonuçlar elde edilebilmesi için ileri çalışmalara ihtiyaç vardır.

\section{Teşekkür}

Bu çalışma Selçuk Üniversitesi BAP Koordinatörlüğü tarafından (No: 11202018) maddi olarak desteklenmiştir. Ayrıca çalışmanın istatistiksel analizi için Selçuk Üniversitesi Diş Hekimliği Fakültesi Protetik Diş Tedavisi Anabilim Dalı'ndan Dr. Serhan Akman'a teşekkür ederiz. 


\section{KAYNAKLAR}

Akman M, Belli S, Olcay K, Ozcopur B, 2016. The Effect of Boric Acid on Root Dentin Mineral Content and Bond Strength of AH-Plus: A SEM-EDX Study. Turkiye Klinikleri Dental J, 22, 14-20.

Altundasar E, Ozçelik B, Cehreli ZC, Matsumoto K, 2006. Ultramorphological and histochemical changes after ER, CR:YSGG laser irradiation and two different irrigation regimes. J Endod, 32, 465-468.

Ari $\mathrm{H}$, Erdemir A, 2005. Effects of Endodontic Irrigation Solutions on Mineral Content of Root Canal Dentin Using ICP-AES Technique. J Endod, 31, 187-189.

Borges RP, Sousa-Neto MD, Versiani MA, RachedJúnior FA, De-Deus G, Miranda CE, Pecora JD, 2012. Changes in the surface of four calcium silicatecontaining endodontic materials and an epoxy resinbased sealer after a solubility test. Int Endod J, 2012, $45,419-428$.

Celik K, Belli S. Kök kanal tedavilerinde başarısızlık sebepleri, 2012. EÜ Dişhek Fak Derg, 33, 6-12.

Cobankara FK, Adanır N, Belli S, 2004. Evaluation of the Influence of Smear layer on the Apical and Coronal Sealing ağabeylity of two Sealers. J Endod, 30, 406409.

Cobankara FK, Erdogan H, Hamurcu M, 2011. Effects of chelating agents on the mineral content of root canal dentin. Oral Surg Oral Med Oral Pathol Oral Radiol Endod, 112, e149-154.

Capar ID, Aydinbelge HA, 2013. Surface change of root canal dentin after the use of irrigation activation protocols: electron microscopy and an energydispersive X-ray microanalysis. Microsc Res Tech, 76, 893-896.

De-Deus G, Paciornik S, Mauricio MH, 2006. Evaluation of the effect of EDTA, EDTAC and citric acid on the microhardness of root dentine. Int Endod J, 39, 401407.

Di Renzo M, Ellis TH, Sacher E, Stangel I, 2001. A photoacoustic FTIRS study of the chemical modifications of human dentin surfaces: II. Deproteination. Biomaterials, 22, 793-797.

Dogan H, Çalt S, 2001. Effects of chelating agents and sodium hypochlorite on mineral content of root dentin. J Endod, 27(9), 578-580.

Doğan H, Taşman F, Çehreli ZC, 2001. Effect of guttapercha solvents at different temperatures on the calcium, phosphorus and magnesium levels of human root dentin. J Oral Rehabil, 28, 792-796.

Erdemir A, Eldeniz AU, Belli S, 2004. Effect of guttapercha solvents on mineral contents of human root dentin using ICP-AES technique. J Endod, 30, 54-56.
Flores DS, Rached-Ju' nior FJ, Versiani MA, Guedes DF, SousaNeto MD, Pe'cora JD, 2010. Evaluation of physicochemical properties of four root canal sealers. Int Endod J, 44, 126-135.

Gandolfi MG, Taddei P, Tinti A, De Stefano Dorigo E, Rossi PL, Prati C, 2010. Kinetics of apatite formation on a calcium-silicate cement for rootend filling during ageing in physiological-like phosphate solutions. Clin Oral Investig, 14, 659668.

Gurbuz T, Ozdemir Y, Kara N, Zehir C, Kurudirek $M, 2008$. Evaluation of root canal dentin after $\mathrm{Nd}$ :YAG laser irradiation and treatment with five different irrigation solutions: a preliminary study. $J$ Endod, 34, 318-321.

Hennequin M, Douillard Y, 1995. Effects of citric acid treatment on the $\mathrm{Ca}, \mathrm{P}$ and $\mathrm{Mg}$ contents of human dental roots. J Clin Periodontol, 22, 550557.

Hennequin M, Pajot J, Avignant D, 1994. Effects of different $\mathrm{pH}$ values of citric acid solutions on the calcium and phosphorus contents of human root dentin. J Endod, 20, 551-554.

Kang D, Amarasiriwardena D, Goodman AH, 2004. Application of laser ablation-inductively coupled plasma-mass spectrometry (LA-ICP-MS) to investigate trace metal spatial distributions in human tooth enamel and dentine growth layers and pulp. Anal Bioanal Chem, 78, 1608-1615.

Kawasaki K, Ruben J, Stokroos I, Takagi O, Arends J, 1999. The remineralization of EDTA treated human dentine. Caries Res, 33, 275-280.

Mello I, Coil J, Antoniazzi JH, 2009. Does a final rinse to remove smear layer interfere on dentin permeability of root canals? Oral Surg Oral Med Oral Pathol Oral Radiol Endod, 107, e47-51.

Oyarzun A, Cordero AM, Whittle M, 2002. Immunohistochemical evaluation of the effects of sodium hypochlorite on dentin collagen and glycosaminoglycans. J Endod, 28, 152-156.

Perdigao J, Eiriksson S, Rosa BT, Lopes M, Gomes G, 2001. Effect of calcium removal on dentin bond strengths. Quintessence Int, 32, 142146.

Pérez-Heredia M, Ferrer-Luque CM, GonzálezRodríguez MP, Martín-Peinado FJ, GonzálezLópez S, 2008. Decalcifying effect of 15\% EDTA, $15 \%$ citric acid, $5 \%$ phosphoric acid and $2.5 \%$ sodium hypochlorite on root canal dentine. Int Endod J, 41, 418-423. 
Qian W, Shen Y, Haapasalo M, 2011. Quantitative analysis of the effect of irrigant solution sequences on dentin erosion. J Endod, 37, 1437-1441.

Resende LM, Rached-Junior FJ, Versiani MA, SouzaGabriel AE, Miranda CE, Silva-Sousa YT, Sousa Neto MD, 2009. A comparative study of physicochemical properties of AH Plus, Epiphany, and Epiphany SE root canal sealers. Int Endod J, 42, 785-793.

Rotstein I, Dankner E, Goldman A, Heling I, Stabholz A, Zalkind M, 1996. Histochemical analysis of dental hard tissues following bleaching. J Endod, 22, 23-25.

Sakae T, Mishima H, Kozawa $Y, 1988$. Changes in bovine dentin mineral with sodium hypochlorite treatment. J Dent Res, 67, 1229-1234.

Saleh AA, Ettman WM, 1999. Effect of endodontic irrigation solutions on microhardness of root canals dentine. J Dent, 27, 43-46.

Saleh IM, Ruyter IE, Haapasalo M, Ørstavik D, 2002. The effects of dentine pretreatment on the adhesion of root-canal sealers. Int Endod J, 35, 859-866.

Saunders WP, Saunders EM, 1994. Coronal leakage as a cause of failure in root canal therapy: a review. Endod Dent Traumato, 10, 105-108.

Sayin TC, Cehreli ZC, Deniz D, Akcay A, Tuncel B, Dagli F, Gözükara H, Kalaycı S, 2009. Time-dependent decalcifying effects of endodontic irrigants with antibacterial properties. J Endod, 35, 280-283.

Sayin TC, Serper A, Cehreli ZC, Kalayci S, 2007. Calcium loss from root canal dentin following EDTA, EGTA, EDTAC, and tetracycline- $\mathrm{HCl}$ treatment with or without subsequent $\mathrm{NaOCl}$ irrigation. J Endod, 33, 581-584.

Schafer E, Zandbiglari T, 2003. Solubility of root-canal sealers in water and artificial saliva. Int Endod J, 36, 660-669.

Spano JC, Silva RG, Guedes DF, Sousa-Neto MD, Estrela C, Pécora JD, 2009. Atomic absorption spectrometry and scanning electron microscopy evaluation of concentration of calcium ions and smear layer removal with root canal chelators. J Endod, 35, 727-730.

Timpawat S, Harnirattisai C, Senawongs P, 2001. Adhesion of a glassionomer root canal sealer to the root canal wall. J Endod, 27, 168-171.

Topçuoğlu HS, Köseoğlu M, 2015. Effect of Er:YAG and $\mathrm{Nd}$ :YAG lasers on the mineral content of root canal dentin. Lasers Med Sci, 30, 809-813.
Wiesmann HP, Tkotz T, Joos U, Zierold K, Stratmann U, Szuwart T, Plate U, Höhling HJ, 1997. Magnesium in newly formed dentin mineral of rat incisor. J Bone Miner Res, 12, 380-383.

Zehnder M, Schmidlin P, Sener B, Waltimo. Chelation in root canal therapy reconsidered, 2005. J Endod, 31, 817-820.

Yazışma Adresi:

Keziban OLCAY

İstanbul Medipol Üniversitesi

Diş Hekimliği Fakültesi Endodonti AD

Atatürk Bulvarı, No:27, Unkapanı, Fatih, Istanbul

Tel : +902124534800-4958

Faks : +90 3322230062

E-mail: kolcay@medipol.edu.tr 